\title{
MUDANÇAS NA LEGISLAÇÃO MIGRATÓRIA BRASILEIRA: PROPOSTAS A PARTIR DA INTERNACIONALIZAÇÃO DOS DIREITOS HUMANOS
}

\author{
CAMBIAMENTI NELLA LEGISLAZIONE BRASILIANA DI IMMIGRAZIONE: \\ PROPOSTE A PARTIRE DALL'INTERNAZIONALIZZAZIONE DEI DIRITTI \\ UMANI
}

\begin{abstract}
${ }^{1}$ Lino Rampazzo
${ }^{2}$ Aline Marques Marino

\section{RESUMO}

Este trabalho pretende discutir a situação da migração interna no Brasil dentro da Lei $\mathrm{n}^{\mathrm{o}} 6.815$ /1980, denominada Estatuto do Estrangeiro, tomando como referência os projetos de lei em trâmite nas Casas Legislativas (PL no 5.655/2009 e PL n 288/2013), comparando, assim, essas normas, em meio ao Direito Internacional dos Direitos Humanos, de modo a compatibilizar com a Constituição Federal de 1988 e com normas internacionais promulgadas pelo Brasil, que trazem a igualdade entre brasileiro e estrangeiro e princípios necessários à concretização da dignidade da pessoa humana. Coloca-se o seguinte problema: a atual legislação supre as demandas do mundo globalizado? As respostas para este questionamento encontrarão respaldo nas ideias de reformulação do conceito tradicional de cidadania, com o propósito de não se tornar inaplicável a universalidade dos Direitos Humanos, bem como na proposta de modificação do artigo $4^{\circ}$, $\S 5^{\circ}$, do PL n ${ }^{\circ} 288 / 2013$, para estender garantias aos imigrantes não registrados (ilegais), a fim de não estimular o trabalho escravo e o tráfico de pessoas. Utilizar-se-á como métodos a revisão bibliográfica na literatura jurídica e o exame crítico das normas pertinentes.
\end{abstract}

Palavras-chave: Migração interna, Lei no 6.815/1980, Pl nº 5.655/2009, Pl nº 288/2013, Direitos humanos

\footnotetext{
${ }^{1}$ Doutor em Teologia pela Pontifícia Universidade Lateranense - PUL, Roma (Itália). Professor pela Centro Universitário Salesiano São Paulo - UNISAL, São Paulo (Brasil). E-mail: lino.rampazzo@uol.com.br

${ }^{2}$ Mestre em Concretização dos Direitos Difusos e Coletivos pela Centro Universitário Salesiano de São Paulo U.E. de Lorena - UNISAL, São Paulo (Brasil). Professora de Direito pela Universidade Federal de Itajubá UNIFEI, Minas Gerais (Brasil). E-mail: $\underline{\text { alinemarinoadv@gmail.com }}$
} 


\begin{abstract}
Questo articolo si propone di discutere la situazione delle migrazioni interne in Brasile dentro la Legge $n^{\circ}$ 6.815/1980, denominata Statuto dello Straniero, prendendo come riferimento i progetti di legge in tramitazione nelle Camere Legislative (Disegno di Legge $n^{\circ}$ 5655/2009 e Disegno di Legge $\mathrm{n}^{\circ}$ 288/2013), confrontando, così, queste norme, dentro il Diritto Internazionale dei Diritti Umani, al fine di adeguarli con la Costituzione Federale del 1988 e con le norme internazionali promulgate dal Brasile, che riconoscono l'uguaglianza tra brasiliani e stranieri e i principi necessari per la concretizzazione della dignità della persona umana. Si pone il seguente problema: la legislazione attuale soddisfa le esigenze del mondo globalizzato? Le risposte a questa domanda troveranno supporto nelle idee di riformulazione del concetto tradizionale di cittadinanza, perché non diventi inapplicabile l'universalità dei Diritti Umani, come pure nella proposta di modifica dell'articolo $4^{\circ}, \S^{\circ} 5$ del Disegno di Legge $n{ }^{\circ} 288 / 2013$, per concedere garanzie agli immigrati non registrati (illegali), in modo da non stimolare il lavoro schiavista e il traffico di esseri umani. La metodologia utilizzata sarà quella della revisione della letteratura giuridica e l'esame critico delle norme pertinenti.
\end{abstract}

Keywords: Migrazione interna, Legge $n^{\circ} n^{\circ} 6.815 / 1980$, Disegno di legge $n^{\circ} 5.655 / 2009$, Disegno di legge $n^{\circ}$ 288/2013, Diritti umani 


\section{Introdução}

O tema Estrangeiros no Brasil, apesar de ser um tanto quanto antigo, tendo em vista que as migrações sempre ocorreram no mundo, ganha relevância diante de várias notícias divulgadas atualmente, entre elas a entrada de haitianos no Brasil, a partir de 2010, seja por causas naturais (terremoto), seja para fugir da pobreza e para buscar condições dignas de vida (RAMALHO, 2015), bem como o naufrágio que ocasionou a morte de imigrantes irregulares que saíam da costa da Líbia com destino à Itália (ORDAZ, 2015), o que justifica o estudo deste assunto, sobretudo para a elaboração de Políticas Públicas capazes de solucionar as situações daí decorrentes da melhor forma possível.

Quando se fala em nível de Brasil, como é o caso do presente estudo, a problemática que se coloca é: a legislação em vigor consegue suprir a realidade fática? Para responder a este questionamento, o trabalho que segue foi subdividido em quatro tópicos.

No primeiro tópico, busca-se demonstrar a importância do assunto migração na História do Brasil, país formado por imigrantes de diversas nacionalidades (portugueses, espanhóis, holandeses, africanos, latino-americanos, alemães, japoneses, italianos, haitianos, entre outros), desde o início, com a colonização, passando por rotas migratórias distintas a depender do período analisado, ora de intenso fluxo migratório, ora de emigração.

No segundo tópico, ater-se-á às mudanças na legislação brasileira no que se refere ao estrangeiro, pois há dois projetos de lei, o de $n^{\circ} 5.655 / 2009$, em trâmite perante a Câmara dos Deputados, e o de n⿳0 288/2013, em discussão no Senado Federal, ambos no intuito de revogar o Estatuto do Estrangeiro (Lei $n^{\circ}$ 6.815/1980), norma atualmente em vigor, datada do período da Ditadura Militar e que não condiz com a Nova Ordem Internacional fruto da globalização.

No terceiro tópico, passa-se ao exame da ideia de cidadania em meio ao universalismo e ao interculturalismo dos Direitos Humanos.

Por fim, no último tópico, parte-se para o exame crítico, alicerçado tanto nas mudanças legislativas, quanto na noção de cidadania, argumentando-se em prol da efetivação dos Direitos Humanos, sob pena de tornar a universalidade mero preceito programático, sem qualquer eficácia e sem eficiência.

A atualidade do debate sobre a migração no país no âmbito legislativo justifica a escolha do tema.

Utilizar-se-á como métodos a revisão bibliográfica na literatura jurídica e o exame crítica das normas pertinentes. 


\section{Migrações e História do Brasil}

A migração é um fenômeno que sempre existiu na história humana e a causa que resume o porquê é a busca por melhores condições de vida. Entendida como o movimento de pessoas em determinado espaço geográfico, a migração pode ser interna, quando ocorre dentro do território nacional, ou pode ser internacional, quando transcende as fronteiras políticas de um Estado. As justificativas para a ocorrência são várias: perseguição política, religiosa, étnica, questões ambientais, melhores condições de trabalho e de estudo, podendo, a depender do fundamento, ser forçada ou convencional (CLARO, 2015).

Atualmente, o panorama das migrações vem ganhando contornos específicos e que demandam mudanças em meio a era globalizada. No contexto das alterações climáticas, dos desastres ambientais, da escassez de oportunidades no mercado de trabalho e da necessidade de contribuição internacional entre os países, milhares de pessoas saem do habitat originário, onde seus costumes, suas tradições, seus modos de vida já estão enraizados, e vão para outras cidades, outros Estados, outros países.

No Brasil, em específico, os dados mostram fluxos migratórios diferenciados, o que contribui para a miscigenação e hábitos culturais distintos ao redor do país. Segundo o levantamento feito pelo Centro de Estudos Migratórios, da Missão Paz, de 1559 a 1888, os africanos eram trazidos como escravos. De 1871 a 1930, ocorreu a chegada de 4 milhões de imigrantes, sendo 60\% para o Estado de São Paulo e a maioria composta por italianos, portugueses e espanhóis e, em menor número, alemães e suíços. De 1910 a 1920, houve a chegada de sírios-libaneses, japoneses e judeus. Dos anos 1930 a 1990, estima-se que chegaram ao Brasil cerca de 500 mil imigrantes e, no meio deste período (1940-1960), foi registrada, também, a imigração residual desses grupos que já estavam aqui fixados. No pós Segunda Guerra Mundial, houve a chegada de aproximadamente 300 mil imigrantes provenientes do Leste Europeu, como Bulgária, Croácia, Eslovênia, Estônia, Letônia, Hungria, Lituânia, Polônia, Rússia, e Ucrânia. A partir de 1960, entraram os coreanos, chineses e latinoamericanos (bolivianos, peruanos, equatorianos e paraguaios). A partir de 1990, vieram imigrantes da África (Nigéria, Angola, Moçambique, Costa do Marfim, Congo, Senegal). Do ano de 2010 até o presente, continua a chegada dos africanos, acrescida da pessoas oriundas do Bangladesh e, com destaque, a chegada de haitianos, em razão do terremoto de 2010, no Haiti (PARISE, 2015).

O Brasil, por formação, é um país composto de imigrantes, por uma realidade miscigenada. No início, os povos nativos, indígenas. Com o tempo, tornou-se um local 
estratégico para a colonização, tendo em vista as condições de riquezas naturais e a extensão territorial. Começa o pau-brasil, passa-se à cana-de-açúcar, em seguida, o café, sobrevivência na realidade nacional e internacional por meio de commodities. Disputas pelo poder, da Monarquia à República, Ditadura Militar, Estado Novo, República do café-com-leite, Parlamentarismo, Presidencialismo. E, no meio de toda essa história, a chegada de imigrantes portugueses, italianos, franceses, alemães, espanhóis, japoneses, africanos, sírios, turcos e haitianos, entre outras nacionalidades, fazendo do país um terreno de realidades socioculturais e econômicas múltiplas, o que dificulta a adoção de Políticas Públicas voltadas para o bem- estar de todos em razão de toda essa diversidade que concretiza uma realidade, simultaneamente, com e sem identidades, porque este contexto contribui para formar pequenos grupos em locais distantes entre si que lutam pelo direito de manter seus costumes, o que coloca em debate a efetividade do princípio federativo, eis que se tem a necessidade de legislar para todos, abstratamente, e, ao mesmo tempo, adequar-se às particularidades.

A vinda de imigrantes trazidos pelos colonizadores fomentou a exploração da mão-deobra e o tráfico de pessoas. No decênio da Independência, a média anual de ingresso de escravos no Brasil era de 32770 cativos, no período de 1811-1820, e de 43140 cativos, no período de 1821-1830. A maioria deles foi enviada para as lavouras cafeeiras do Vale do Paraíba ou ficou no Rio de Janeiro. As necessidades da lavoura do café contribuíram para a expansão do tráfico de escravos.

Para combater esse quadro de atrocidade, ocorreu interferência internacional, mais especificamente da Inglaterra que, em 1826, formulou um Tratado com o Brasil estabelecendo que, após três anos da ratificação, seria declarado ilegal o tráfico de escravos para o Brasil, reservando-se, inclusive, o direito de inspecionar navios em alto-mar que fossem suspeitos de comércio ilegal (FAUSTO, 1995, p. 192).

Em 1831, foi estabelecida norma prevendo penas aos traficantes, porém, “os júris locais, controlados pelos grandes proprietários, absolviam os poucos acusados que iam a julgamento" (FAUSTO, 1995, p. 192), pois os traficantes, à época, ainda não eram malvistos nas camadas dominantes. A escolha pelos escravos se justificava pela inexistência de alternativas viáveis ao trabalhador cativo e, também, porque não havia rebelião generalizada, salvo exceções de negros africanos, escravos e libertos muçulmanos, em Salvador, conhecida como Revolta dos Malês. Ressalta-se, ainda, que a legislação trabalhista data de 1943. A pressão externa na extinção do tráfico ficou marcada com o Bill Aberdeen, em que a Inglaterra apreendeu navios que transportavam escravos. 
Em 1850, os efeitos das normas legais começam a aparecer. A entrada de escravos no país caiu de cerca de 54 mil cativos (1849) para menos de 23 mil (1850), e em torno de 3300 (1851). O Brasil era invadido pela Argentina através de navios suspeitos de contrabandear escravos e necessitava de proteção inglesa. No final de 1840, fazendeiros fluminenses tinham hipotecado suas propriedades para grandes traficantes, para obter recursos destinados à compra de escravos (FAUSTO, 1995, p. 196).

A Lei de Terras, de 1850, colocou ordem à propriedade rural, de forma a evitar o acesso à propriedade da terra por parte de futuros imigrantes, estabelecendo que "as terras públicas deveriam ser vendidas por um preço suficientemente elevado para afastar posseiros e imigrantes pobres" (FAUSTO, 1995, p. 196). Após 1850, o suprimento de cativos se deu através do tráfico interprovincial, com a transferência forçada de escravos de uma região para outra.

Entre 1887 e 1930, cerca de 3,8 milhões de estrangeiros entraram no Brasil em razão de demanda por mão-de-obra para a lavoura de café, a maioria italianos $(35,5 \%)$. No período de 1931-1940, ocorreu a entrada maciça de japoneses (FAUSTO, 1995, p. 275).

Percebe-se que, desde os anos mais remotos do descobrimento até a atualidade, a entrada ilegal de imigrantes é fator comum e frequente, inclusive o modo como isso é feito, na ronda de tráfico, como, por exemplo, a recente entrada de haitianos através de coiotes (SANTINI, 2014). O fato de nos tempos mais antigos isso ser visto como algo comum traz ao contexto de hoje uma certa dose de despenalização dessas condutas ilícitas, trazendo consequências drásticas no mercado de trabalho e na dinâmica da propriedade urbana (direito à moradia), além de incluir os fatores culturais.

Para corroborar com a situação de irregularidade, os dados do Censo do IBGE de 2010 apontam que a crise internacional atraiu imigrantes ao Brasil e que o número quase dobrou na década, sendo os Estados de São Paulo e Paraná os principais destinos, e as nacionalidades são várias, incluindo haitianos, sírios e bolivianos. Em contrapartida, estima-se que residam no exterior entre 491.243 e 2,5 milhões de brasileiros $^{1}$ (IBGE, 2010). Com estes números e com as consequências advindas do processo migratório, tem-se a necessidade de se regulamentar juridicamente direitos e deveres, com o propósito de melhor tutelar a situação dos imigrantes e, também, dos brasileiros que emigram. Vejamos alguns detalhes da legislação no que tange ao estrangeiro e possíveis sugestões para melhor adequar os à realidade do Brasil.

\footnotetext{
${ }^{1}$ Para maiores informações, o site é bastante elucidativo. Cf. IBGE. Censo Demográfico de 2010. Disponível em: <http://www.ibge.gov.br/home/estatistica/populacao/censo2010/default.shtm>. Acesso em: 25 jun. 2015.
} 


\section{As mudanças na legislação brasileira quanto ao estrangeiro: abordagem à luz da Lei $n^{0}$ 6.815/1980, do PL 5.655/2009 e do PL 288/2013²}

Tendo em vista as rotas migratórias dos últimos anos, não necessariamente pelos números que, se verificados nas estatísticas do Ministério das Relações Exteriores e do IBGE, a composição da população brasileira seria de aproximadamente $1 \%$ de imigrantes, mas, principalmente, por causa da repercussão que este tema representa no mundo, o Direito tem a necessidade de refletir as situações fáticas por meio de normas que as regulamentem, ainda que, timidamente, de início, o faça somente no plano principiológico.

Atualmente, a principal norma interna que regulamenta a situação jurídica do estrangeiro no Brasil é a Lei ${ }^{\circ}$ 6.815, de 19 de agosto de $1980^{3}$ que, em meio ao contexto da Ditadura Militar, estabeleceu que a concessão do visto deve ser condicionada aos interesses nacionais (artigo $3^{\circ}$ ), depreendendo-se deste dispositivo a predominância da soberania no sentido mais clássico e tradicional, muitas vezes mais preocupada com os interesses nacionais, em detrimento de toda a ordem internacional, ainda que estejamos num mundo globalizado.

A título de exemplificação, a Lei $n^{\circ}$ 6.815/1980, além do artigo $3^{\circ}$, acima mencionado, faz referência aos interesses nacionais em outros dispositivos, tais como: no artigo $1^{\circ}$, em que resguarda o interesse nacional; no artigo $7^{\circ}$, que impõe a não concessão de visto ao estrangeiro considerado nocivo aos interesses nacionais; no artigo $57, \S 2^{\circ}$, que estabelece a desnecessidade de fixação de prazo para deportação de estrangeiro por motivos de entrada ou estada iregular em caso de conveniência aos interesses nacionais; no artigo 65, que prevê a possibilidade de expulsão do estrangeiro se este praticar algo nocivo à conveniência e aos interesses nacionais; no artigo 110, que deixa margem de discricionariedade ao Ministro da Justiça para impedir a realização, por estrangeiros, de conferências, congressos e exibições artísticas ou folclóricas; e no artigo 130, que autoriza o Poder Executivo a firmar acordos internacionais, desde que a condição de respeito aos interesses nacionais seja efetivada.

\footnotetext{
${ }^{2}$ Em apenso, consta também o PL no $2.516 / 2015$.

${ }^{3}$ A Lei n ${ }^{\circ} 6.815 / 1980$ foi regulamentada pelo Decreto ${ }^{\circ} 86.715$, de 10 de dezembro de 1981.

Em ordem cronológica e para efeitos didáticos, Carolina de Abreu Batista Claro (2015), fez um levantamento das normas internas brasileiras sobre migração, do século XIX até o presente. Ao observar os dados expostos pela autora, percebe-se que a maior parte das normas já foram revogadas e que a grande maioria são resoluções do Conselho Nacional de Imigração (CNIg). É interessante perceber que, de todas as normas citadas pela autora, das que estão totalmente em vigor, 92 foram produzidas no século XXI, 21, na segunda metade do século XX, e 1 na primeira metade do século XX.
} 
Igualmente, o mesmo diploma legal, em várias ocasiões, faz referência à segurança nacional. Por exemplo: no artigo $2^{\circ}$, a norma é imperativa ao colocar a segurança nacional como algo a ser observado na interpretação dos demais dispositivos; e no artigo 65 , há a possibilidade de expulsão do estrangeiro que de qualquer forma atentar contra a segurança nacional.

É óbvio que, para o contexto de época, 1980, em que o Brasil viveu as mais doloridas histórias de restrições às liberdades e aos direitos e garantias fundamentais como um todo, a redação trazida pela Lei $\mathrm{n}^{\circ} 6.815$ não passa de efeitos provenientes dos fatos então vividos. Em suma, um país fechado aos interesses internacionais, monopólio de força do Estado dentro de seu próprio território, o que dificulta, inclusive, a emancipação de uma disciplina autônoma de Direito Internacional capaz de conceber um sujeito de direitos em âmbito internacional, juntamente com o Estado, ou seja, um Estado cuja formação é de uma sociedade de sociedades, diferente da concepção clássica, que não engloba outros sujeitos além do Estado, que, pela contextualização histórica é a que parece predominar, embora haja uma nítida tendência de mudança do tradicional (D’AURIA, 2013) .

Em que pese a Lei 6.815/1980 estar ainda em vigor, há projetos de lei no sentido de trazer mudanças e até mesmo de revogá-la inteiramente, convergindo para uma nova política migratória que releve o desenvolvimento socioeconômico e cultural do Brasil. Assim, o foco passa da segurança nacional para o direito do homem à migração, colocando em prática o que o Brasil, antes mesmo de publicar a Lei 6.815/1980, já havia assinalado ao promulgar a Carta das Nações Unidas que, na ementa, esclarece entre as finalidades: "praticar a tolerância e viver em paz, uns com os outros, como bons vizinhos" (COMPARATO, 2013, p. 231). Como exemplos de mobilização para esta mudança legislativa, temos o Projeto de Lei $\mathrm{n}^{\circ}$ 5.655/2009, do Poder Executivo, e o Projeto de Lei nº 288/2013, do Senado Federal.

O Projeto de Lei ${ }^{\circ} 5.655 / 2009$, de autoria do Poder Executivo, foi apresentado em 20 de julho de 2009, na Câmara dos Deputados, e revoga na íntegra a Lei nº 6.815/1980. Encontra-se aguardando parecer do Relator na Comissão de Relações Exteriores e de Defesa Nacional (CREDN). De acordo com Tarso Genro, à época Ministro da Justiça, as principais inovações são:

(...) (i) a atuação de estrangeiros em regiões consideradas estratégicas, como é o caso das áreas indígenas, homologadas ou não, e das áreas ocupadas por quilombolas ou

\footnotetext{
${ }^{4}$ Neste sentido, Flávia Piovesan (1996) sugere a formação de um Direito Constitucional Internacional, a fim de articular as ordens interna e externa, isto é, algo que busque os interesses nacionais, como também internacionais, desde que harmônicos entre si.
} 


\begin{abstract}
por comunidades tradicionais, somente poderá ocorrer mediante prévia autorização dos órgãos competentes; (ii) ampliação de quatro para dez anos do prazo mínimo para naturalização ordinária, podendo ser reduzido para cinco anos em situações específicas; (iii) regulação da naturalização extraordinária; (iv) a incorporação da jurisprudência do Supremo Tribunal Federal sobre extradição visando solucionar controvérsias como a possibilidade de extradição de brasileiro naturalizado, por envolvimento em tráfico ilícito de entorpecentes e drogas afins, quando o crime for caracterizado com prova da materialidade e indícios de autoria e a flexibilização da exigência de dupla incriminação, dentre outros; (v) a transformação do Conselho Nacional de Imigração em Conselho Nacional de Migração, na estrutura básica do Ministério do Trabalho e Emprego, que permitirá ampliar o foco e abarcar situação de grande contingente de brasileiros no exterior, de modo a ensejar o estabelecimento de uma política nacional de migração; e (vi) a revogação da Lei no 6.815, de 1980, da Lei no 6.964, de 1981, e do inciso I do art. $5^{\circ}$ da Lei n $^{\circ} 8.422$, de 13 de maio de 1992. (PROJETO DE LEI n ${ }^{\circ} 5.655 / 2009$ ).
\end{abstract}

Já o Projeto de Lei no 288/2013, de autoria do Senador Aloysio Nunes Ferreira, dispõe sobre os direitos e deveres do migrante e regula a entrada e estada de estrangeiros no Brasil, além de estabelecer normas de proteção ao emigrante brasileiro, revogando, em parte, a Lei no 6.815/1980. O último andamento data de 02 e julho de 2015, com apresentação do texto final aprovado e encaminhado ao Presidente do Senado. Busca focar o migrante, e não mais o estrangeiro, no contexto da proteção internacional dos Direitos Humanos, em que vigoram os princípios da interdependência, da universalidade e da indivisibilidade.

A justificativa para a ênfase humanitária encontra respaldo na História do Brasil marcada por fluxos migratórios, já referida em um dos tópicos deste trabalho, além do alicerce constitucional, mais especificamente o artigo $4^{\circ}$, que coloca entre os princípios que regem nossas relações internacionais, a prevalência dos Direitos Humanos, o repúdio ao racismo e a busca pela integração econômica, política, social e cultural dos povos da América Latina, visando à formação de uma comunidade latino-americana de nações.

Os projetos de lei mencionados guardam coerência com a Constituição Federal de 1988, à medida que esta traz a dignidade da pessoa humana como pilar da República Federativa do Brasil, consoante se percebe da leitura do artigo $1^{\circ}$, inciso III.

Na mesma esteira, o Ministério da Justiça, através da Portaria $n^{\circ} 2.162 / 2013$, criou uma Comissão de Especialistas com a finalidade de apresentar uma proposta de Anteprojeto de Lei de Migrações e Promoção dos Direitos dos Migrantes no Brasil, a qual definiu as cinco principais características da proposta: a) compatibilidade com a Constituição Federal de 1988 e respeito ao princípio da convencionalidade; b) mudança de paradigma, saindo da segurança nacional para o prisma dos Direitos Humanos; c) coerência sistêmica com o Direito Constitucional Brasileiro e com o Direito Internacional dos Direitos Humanos; d) criação de 
um órgão estatal especializado para atendimento dos migrantes; e e) preparar o Brasil para enfrentar a globalização econômica (ANTEPROJETO, 2014).

Recentemente, alguns fatos que ganharam as páginas dos jornais contribuem para fazer pressão social no intuito de dar a devida prioridade à tramitação destes projetos de lei. Provas disso são o naufrágio na costa italiana e a chegada de haitianos pela fronteira BrasilPeru, por meio do Acre. A irregularidade e a ação dos coiotes, que acabam intensificando o tráfico de pessoas, demonstram a necessidade de uma política migratória mais eficaz. A situação que se coloca é como conviver com a realidade, de modo a não abarcar possíveis soluções que sirvam como válvulas de escape àquilo que sempre aconteceu, porém que só ganhou maior notoriedade agora. É certo que uma política de migração mais restritiva demandaria alto investimento no setor de segurança, e a prioridade em outras políticas públicas mais urgentes ficariam defasadas.

Deisy Ventura e Rossana Rocha Reis (2014), em artigo de opinião escrito para a Revista Carta Capital, defendem que a Lei 6.815/1980, conhecida como "Estatuto do Estrangeiro", tem como características "o alto grau de restrição e burocratização da regularização migratória, a discricionariedade absoluta do Estado, a restrição dos direitos políticos e da liberdade de expressão, além da explícita desigualdade em relação aos direitos humanos dos nacionais". Também, seria difícil um paradigma contrário deste, já que tal diploma legal data do governo do general João Figueiredo, em plena ditadura militar.

No mesmo sentido, caminha o pensamento do Presidente do Conselho Nacional de Imigração (CNIg), Paulo Sérgio de Almeida, pois “ainda temos uma lei de 1980, uma época em que o país vivia uma época de exceção e que tem um viés autoritário. É uma dívida que o país tinha em relação a essa questão" (EL PAÍS, 2015) e do procurador federal dos Direitos do Cidadão, Aurélio Rios, que enfatiza o princípio da solidariedade, ao fazer referência à situação dos haitianos (SENADO, 2014).

Além disso, na esfera da sociedade civil, principalmente no que tange à participação da igreja no acolhimento dos imigrantes, Rosita Milesi, do Instituto Migrações e Direitos Humanos, após breves reminiscências históricas das Constituições brasileiras, passando pela legislação alienígena, entre elas a Declaração Universal dos Direitos Humanos (1948), o Pacto Internacional sobre Direitos Civis e Políticos (1966), o Pacto de San José da Costa Rica (1992) e a Convenção Internacional para a Proteção dos Direitos de todos os Trabalhadores Migrantes e seus Familiares (1990), considera que “o horizonte a ser buscado é o da cidadania universal dos migrantes, que não pode diferir daquela de que é portador o cidadão nacional” (MILESI, 2015). 
A história brasileira, imersa na realidade de fato, deixa evidente esta necessidade de mudanças na legislação, a começar pela irregularidade na chegada de muitos imigrantes, bem como as dificuldades nos trâmites com a documentação, em decorrência da burocracia. Do contrário, restaríamos no que Boaventura de Sousa Santos chama de "consenso liberal", o qual se manifesta na crise da democracia e, em consequência, do Estado Social, desdobrandose em “consenso econômico neoliberal”, “consenso do Estado fraco”. "consenso democrático liberal" e "consenso do primado do Direito e dos Tribunais" (SANTOS, 2002).

Para complementar, Sarlet explica que a crise dos direitos fundamentais, como ocorre no caso dos estrangeiros, não se limita à eficácia e à efetividade, abrangendo também "uma crise na esfera do próprio reconhecimento e da identidade dos direitos fundamentais" (SARLET, 2001, p. 09), em que os direitos fundamentais são vistos em dupla perspectiva, negativa, referente à ingerência do Poder Público na esfera individual, e positiva, quando se fala em exercício da liberdade e exigência de omissão para evitar lesões (CANOTILHO, 1992, p. 552). Na situação ora em análise, utilizando-se da terminologia de José Afonso da Silva, tem-se que estabelecer a eficácia social da norma, porque não basta somente a eficácia jurídica, sob pena de inexistir a efetividade (SILVA, 1982, p. 55-56) ${ }^{5}$.

Em meio à referida crise e à reformulação do conceito tradicional de soberania, é imprescindível contextualizar os fatos na nova ordem fruto da globalização. Para Canotilho, tem-se a jusfundamentalidade, enquanto que, para Marcelo Neves, o ideal seria o transcontitucionalismo, de modo que o elemento racionalidade transversal possa abrir-se para a cooperação, para a reciprocidade, para pensarmos a relação entre os subsistemas sociais da política e do direito em termos de coordenação (OS CONSTITUCIONALISTAS, 2009).

\begin{abstract}
As ordens estatais, internacionais, supranacionais, transnacionais e locais, consideradas como tipos específicos, são incapazes de oferecer, isoladamente, respostas complexamente adequadas para os problemas normativos da sociedade mundial. (...) O transconstitucionalismo, como modelo de entrelaçamento que serve à racionalidade transversal entre ordens jurídicas diversas, abre-se a uma pluralidade de perspectivas para a solução de problemas constitucionais, melhor adequando-se às relações entre ordens jurídicas do sistema jurídico hierárquico da sociedade mundial. (NEVES, 2009, p. 131).
\end{abstract}

\footnotetext{
${ }^{5}$ José Afonso da Silva diferencia a eficácia social da eficácia jurídica. A eficácia jurídica "designa a qualidade de produzir, em maior ou menor grau, efeitos jurídicos, ao regular, desde logo, as situações, relações e comportamentos nela indicados; nesse sentido, a eficácia diz respeito à aplicabilidade, exigibilidade ou executoriedade da norma, como possibilidade de sua aplicação jurídica. Possibilidade e não efetividade." (SILVA, 1982, p. 55-56). Assim, nem sempre o que tem eficácia social tem eficácia jurídica, e nem sempre o que tem eficácia jurídica tem eficácia social. O ideal é que tanto a eficácia social quanto a eficácia jurídica estejam juntas para que ocorra a efetividade. Transpondo os conceitos para o assunto ora analisado, tem-se a Lei $\mathrm{n}^{\circ}$ 6.815/1980 somente com eficácia jurídica, mas desprovida da eficácia social, por causa das mudanças na realidade fática que não foram acompanhadas de uma legislação capaz de adequar-se a ela.
} 
Enfim, nessa pluralidade de perspectivas a que Neves se refere, encontra-se a dificuldade de decidir. Neves sugere que se deve verificar a sociedade mundial, a fim de adequar-se. Nas lições de Atienza (1987), busca-se, assim, o razoável e, ao mesmo tempo, o racional ${ }^{6}$. Cabe, então, interpretar o razoável com o propósito de se chegar à decisão mais racional no contexto da sala de aula. Ao que parece, o interculturalismo seria o razoável em sentido estrito.

\title{
3 Reflexões sobre a cidadania em meio ao universalismo e ao interculturalismo dos Direitos Humanos
}

A situação de vida daquele que é oriundo de outro país e chega ao território nacional requer o devido tratamento das peculiaridades, necessárias a proporcionar a integração entre todos. A cidadania, colocada como um dos fundamentos da República Federativa do Brasil (Constituição Federal, artigo $1^{\circ}$, inciso II), é inerente à espécie humana e é compreendida no sentido mais amplo de ter direitos civis, políticos e sociais e que requer providências estatais para a satisfação dos direitos e garantias fundamentais em igualdade de condições (SIQUEIRA JÚNIOR; OLIVEIRA, 2010, p. 246-247). Desse modo, a cidadania é elemento essencial quando se fala em Estado Democrático de Direito. A importância de uma redefinição do tradicional conceito de cidadania se justifica perante a chamada "Nova Ordem Internacional”, como explica Ana Maria D’Ávilla Lopes:

\begin{abstract}
En Europa continental, la exposición de la imigración - provocada por la caída del Muro de Berlin, la Globalización y la consolidación de la Unión Europea - fue el principal factor que motivo el interés por el estudio de uma nueva definición de ciudadanía. La exigencia de considerar la nacionalidad como presupuesto para ser titular de la ciudadanía y, consecuentemente, titular de derechos, asumió el centro de los debates em una realidad em la que practicamente no hay más fronteras geográficas y las personas, y hasta pueblos enteros, se trasladan fácil y frecuentemente de um lugar a outro. (LOPES, 2010, p. 15). ${ }^{7}$
\end{abstract}

\footnotetext{
6 Manuel Atienza, jurista espanhol, no seu clássico texto Para una razonable definición de 'razonable', publicado na Doxa, explica que as decisões jurídicas podem ser classificadas em três grupos: a) razoáveis, mas não estritamente racionais; b) razoáveis e estritamente racionais; e c) não razoáveis (sejam ou não sejam estritamente racionais). Como ideia principal, expõe que todo razoável também é racional, mas nem todo racional é razoável. Assim, uma decisão jurídica será razoável em sentido estrito se e somente se preencher certos requisitos. Vale conferir a redação original: "Uma decisión jurídica es razonable em sentido estricto si y solo si: 1) se toma situaciones em que no sería aceptable, o no se podría, adoptar uma decisión estrictamente racional; 2) logra um equilíbrio entre exigências contrapuestas, pero que necesariamente hay que considerar en la decisión; y 3) es aceptable por la comunidad." (ATIENZA, 1987, p. 193).

7 Tradução livre: Na Europa Continental, a exposição da imigração - provocada pela queda do Muro de Brlim, a Globalização e a consolidação da União Europeia - foi o principal fator que motivou o interesse pelo estudo de
} 
Vale, também, trazer à baila as explicações de Ricardo Lobo Torres que, em artigo sobre este tema, faz uma classificação didática da cidadania que se inicia com a dimensão temporal e chega à cidadania virtual:

Ao lado de suas dimensões temporais a cidadania exibe também as espaciais. Diante de fenômenos nossos contemporâneos, como a globalização, a desestruturação do federalismo e a emergência dos interesses locais, que alteram o relacionamento espaço/tempo, a cidadania postula a visão territorial ou geográfica, transformando-se em cidadania local, nacional, mundial, comunitária, cosmopolita, e, até mesmo, em cidadania virtual, que é o 'fantasma' de todas as outras. (TORRES, 2001, p. 302).

Corroborando com este debate, no intuito de aprofundar a definição de cidadania, Pérez Luño (2002) traz seis conjuntos de acepções lexicais do termo. Vejamos suas principais colocações.

A cidadania pode ser compreendida na acepção decritiva, partindo-se da análise empírica e dos conjuntos de normas que regulam o status jurídico-político dos cidadãos. Este significado é o mais utilizado, sobretudo na teoria juspublicista e nas áreas do Direito Constitucional e do Direito Administrativo. Há, também, a acepção prescritiva, que se adéqua ao significado deontológico e contrafático de um modelo ideal, melhor elaborado no âmbito da Filosofia Moral e Política, em que o autor cita como exemplo Will Kymlicka (LUÑO,

2002), filósofo político canadense, um dos desenvolvedores dos estudos sobre Multiculturalismo, Justiça Social e Direito dos Animais, PhD em Filosofia pela Oxford University e professor no Departamento de Filosofia da Queen's University, em Kingston, no Canadá.

Outros sentidos que o termo "cidadania" traz referem-se ao teórico e ao pragmático. O primeiro (teórico) exige a ampla interdiciplinariedade, além dos aportes doutrinários. Já o pragmático, se alicerça na luta reivindicativa pela consecução de determinadas liberdades ou situações jurídico-políticas, a exemplo dos refugiados e dos imigrantes (LUÑO, 2002).

Para Luño (2002), a cidadania pode advir do natural, ou seja, como fator inato e necessário que determina a inserção do indivíduo em um grupo étnico e cultural ao qual pertence, entendimento que prevalece no Direito Comunitário. É representada por Michael Walzer, que defende que o liberalismo forjou uma noção formal e adjetiva de cidadania, como algo que é exterior ao sujeito. Diferentemente, a acepção política refere-se ao vínculo da

uma nova definição de cidadania. A exigência de considerar a nacionalidade como pressuposto para ser titular da cidadania e, consequentemente, titular de direitos, assumiu o centro dos debates numa realidade em que, praticamente, não há mais fronteiras geográficas e as pessoas e povoados inteiros se movem com facilidade e com frequência de um lugar para outro. 
relação contratual e à adscrição livre das pessoas com a sociedade. Pela leitura do texto de Luño, nota-se que este é um dos tópicos que mais rende controvérsias e para o qual o jurista expõe algumas alternativas, entre elas o humanismo liberal de base kantiana, a tradição nacionalista com base em Johann Herder e o humanismo cosmopolita, também de Kant.

Outro ponto de destaque coloca em pauta as acepções universal e particular de cidadania. Na universal, as abordagens são amplas e o cosmopolitismo se impõe como projeto humanista da modernidade. No plano filosófico, é representada por Martha Nussbaum. No plano jurídicoconstitucional, por Peter Häberle, Fernández García, Llano Alonso e Pérez Luño. Já na particular, pelo contrário, é reduzida à esfera local e, por isso, a cidadania está associada ao pertencimento a um Estado, ideia esboçada pela tradição doutrinária do Direito Público (LUÑO, 2002).

Por último, Luño (2002) descreve as acepções unilateral, em que se dá o vínculo único e exclusivo entre o indivíduo e o Estado, e multilateral, onde se enaltece a pluralidade de cidadanias e coloca em discussão a supraestatalidade e a infraestatalidade. Esta última acepção (multilateral) é muito bem concretizada nos trabalhos de Kymlicka, que elaborou o conceito de "Cidadania Multicultural”, para aplicação junto ao Governo Canadense, por meio do Projeto Index Política de Multiculturalismo (MCP), cujo objetivo é monitorar as respectivas políticas públicas através das democracias ocidentais, fornecer informações sobre políticas de multiculturalismo para auxiliar a investigação comparativa e contribuir para a compreensão das relações entre Estados e Minorias, tendo em vista que o Canadá enfrenta esta problemática em relação aos indígenas e ao Quebec e, também, pelo fato dessas questões trazerem à baila as discussões sobre a identidade dos povos e, em consequência, a emergência de movimentos sociais, experiências individuais e políticas públicas.

Kymlicka formulou suas propostas dentro do contexto do liberalismo, no intuito de encontrar um marco liberal para o tratamento justo dos grupos minoritários, mais especificamente os imigrantes ou poliétnicos e as minorias nacionais. Para o pensador, há as exigências da justiça étnico-cultural em uma democracia liberal, de modo que o direito das minorias deve complementar os direitos humanos, já que a proteção dos direitos humanos individuais é insuficiente para garantir a justiça entre os grupos étnico-culturais, que necessita da partilha do poder, como o federalismo.

Apesar da teoria de Kymlicka ser desenvolvida no Canadá, país de primeiro mundo e com histórico diferente do Brasil, alguns elementos podem ser adaptáveis. Por exemplo, no Capítulo 8, da obra Cidadania Multicultural, o autor traz questionamentos sobre a tolerância, ao exigir a liberdade e a igualdade entre os grupos. Como base para os direitos grupais, 
Kymlicka faz dois argumentos. $\mathrm{O}$ argumento da igualdade é que alguns dos direitos das minorias exigem um tratamento diferente para diferentes grupos. O problema é que, privando grupos de direitos, como a língua e o acesso à terra, pode deixar outro grupo culturalmente desfavorecido e incapaz de participar plenamente na sociedade.

Neste sentido, Diderot y D’Alambert $(1986)^{8}$, na Enciclopédia, colocavam que a cidadania deriva de três grandes princípios: é uma condição da pessoa que vive em uma sociedade livre, porque nos lugares onde existem a tirania ou o arbítrio não há cidadãos; é uma condição voluntária que não se pode impor a nenhuma pessoa; divide-se em um conjunto de direitos e deveres das pessoas que pertencem a um determinado Estado.

Da mesma forma, Kant elabora o conceito de cidadania em base principiológica semelhante a Diderot y D'Alembert: liberdade de cada membro da sociedade, como homem; igualdade perante a qualquer outro, como súdito; e independência de cada membro da comunidade, como cidadão, entendida como poder de participação na vida política. Assim, Kant traz a ideia de cidadania universal, essencial para difundir sua teoria da paz perpétua (KANT, 2006), pois, como esclarece Pisón $(2001)^{9}$, sem as reflexões díspares sobre a tolerância, não teria surgido o interesse pelo desenvolvimento de uma teoria sobre a liberdade individual e, posteriormente, sobre os Direitos Humanos.

A base para a tolerância, em Kymlicka, está na educação do povo. Para o filósofo, é necessário desenvolver mecanismos de integração, como, por exemplo, a participação política por meio do voto dos habitantes do Quebec.

Outros pontos merecedores de destaque são a solidariedade e a unidade social no EstadoNação que, para Kymlicka, são alcançados, principalmente, através da integração e do multiculturalismo, chegando a criar, inclusive, uma identidade cívica comum, chamada de identidade compartilhada.

O tema em análise deixa também em evidência o interculturalismo, dentro da Teoria Crítica dos Direitos Humanos, cujo principal representante é o jurista espanhol Joaquín Herrera Flores. Diferentemente de Kymlicka, traz algumas discordâncias em relação ao

\footnotetext{
${ }^{8}$ Referência a partir de Perez Luño. Para maiores detalhes sobre o texto destes autores, verificar: DIDEROT, D.; D'ALEMBERT, J. L. R. (1751/1765). Artículos políticos de la Enciclopedia. Ed. cast. de R. Soriano y A. Porras. Madrid: Tecnos, 1986.

${ }^{9}$ Apesar de Pisón tratar especificamente da relação entre Estado e Igreja, o suporte teórico traçado por ele cabe também no estudo geral sobre Direitos Humanos. Neste sentido, vale conferir o seguinte trecho, no original: "Estas circunstancias parecen reclamar con insistencia la reivindicación de la universalización 'real' de los derechos humanos, lo que al menos, tiene tres consecuencias: la superación de la visón estatalista de los derechos por una supraestatal, la lucha por la efectividad de los derechos sociales en todo el mundo, y del derecho al desarrollo, y, por fin, la reafirmación de un jurisdicción universal y la creación de una Corte Penal Internacional." (PISÓN, 2001, p. 19).
} 
multiculturalismo, ao dizer que o fator preponderante na questão migratória é o desequilíbrio na distribuição das riquezas, e não a motivação com base na cultura, ou seja, a discussão acerca do processo de migração pauta-se muito mais nos efeitos colaterais do mundo globalizado do que no belo discurso politicamente correto de interferência cultural. Ao que aparenta, a teorização esboçada por Flores é mais realista do que a de Kymlicka.

Quando o foco se dá na cultura, a problematização gira em torno de dogmas e de relavismos, o que Flores denomina de visões abstratas e visões localistas. Na primeira (visão abstrata), tem-se a falta de contexto e o desenvolvimento de determinadas medidas no vazio do existencialismo. Transportando isso para o Brasil, ocorre, por exemplo, quando há necessidade de se fazer uma lei em nível nacional, porém em níveis regional e municipal há defasagem por causa das discrepâncias decorrentes de diferenças. Na segunda (visão localista), ocorre o inverso, isto é, há o excesso de contexto, o que desemboca no mesmo local da visão abstrata, no vazio, correndo o risco de se aceitar cegamente os discursos especializados (FLORES, 2002). No Brasil, um bom exemplo disso é a lei municipal de Pomerode, localizado no Estado de Santa Catarina, que determina a obrigatoriedade do estilo enxaimel/alemão nas construções para manter as tradições e o ambiente turístico (ROTA, 2015; ESTILO, 2015).

A visão abstrata associa-se às práticas universalistas, pecando por ficar no meio termo, no equilíbrio, distante do menos e do mais, porque acaba na média, sem avaliar os pormenores de cada um. Já a visão localista, vê as práticas particularistas, arriscando-se em fechar-se em si mesma, sem verificar o todo (FLORES, 2002).

Flores critica o multiculturalismo, citando como exemplo o caso da União Europeia, em que existe a "guerra de imigração ilegal". Alicerça seu pensamento nas questões sociais, que acaba na criação de clichês discriminatórios face aos imigrantes e, principalmente, centra- se na ausência de visão global da migração, responsável pela falsa ideia de que a motivação é tãosomente a mão-de-obra, sem considerar os conflitos entre os países ricos e pobres em meio ao contexto da globalização selvagem (FLORES, 2002).

Dessa forma, para reconstruir a argumentação, Herrera Flores elabora a visão complexa, onde reina a racionalidade de resistência e a prática intercultural. Se compararmos com Kymlicka, teríamos a "cidadania multicultural" (Kymlicka) e a "cidadania intercultural" (Flores), nem universalista, nem multicultural, mas aberta ao diálogo, à comunicação, embora 
o último não se utilize dessa terminologia. A visão complexa ${ }^{10}$ situa cada indivíduo na periferia, porque nascemos num mundo que já traz uma certa dose de conceitos, de modo que não viemos da neutralidade, pois já existe algo imposto. Essa visão destaca a democracia e a necessidade de participação com decisões tomadas pela coletividade e busca-se a criação de condições com o propósito de desenvolver as potencialidades humanas.

A integração dos imigrantes e, principalmente, dos refugiados é questão relacionada ao direito à cidadania no sentido mais amplo, isso não há dúvidas. Ocorre que por trás deste mesmo direito, principalmente quando se associa à nacionalidade, corre-se o risco de restrigir os direitos fundamentais elementares, como a liberdade de ir e vir e a propriedade, sobretudo no contexto globalizado em que se busca uma resposta aos crescentes fluxos migratórios além das fronteiras. Para se buscar uma luz em torno deste abismo, Ferrajoli (2006) propõe uma superação da cidadania, de modo a desnacionalizar os direitos fundamentais, que são garantias em uma democracia.

Quando se analisa conjuntamente os dados mencionados até então, percebe-se o brilhantismo das colocações do jurista alemão Hermann Heller (1968), ao alertar para a crise do Estado Social de Direito que, ao prever um amplo catálogo de medidas de bem-estar, legitima a pretensão de muitos que as pleiteiam, acabando por deixar no vazio a universalidade dos Direitos Humanos, tendo em vista que a adesão e a distribuição dos direitos e das garantias fundamentais submete-se ao crivo do que se denomina "cultura", como também da base estrutural de que o Estado dispõe para oferecer, com todas as especificidades, sendo que a homogeinização deve ser aplicada considerando-se a isonomia (igualdade real), com vistas à unicidade daquilo que se toma como referencial, o que causa dificuldades em se estabelecer o quê e a quem será distribuído determinado direito ou dever.

A característica universal dos Direitos Humanos é objeto de crítica pelo filósofo francês e estudioso da cultura chinesa François Julien, porque quando se fala em ordem do saber operatório ou prático, tem-se que considerar não somente o que é externo, mas também o indivíduo e, neste sentido, “a fabricação do 'universal' foi excêntrica, para não dizer caótica. Nasceu a partir de projetos múltiplos, e até mesmo inconciliáveis, que culminaram na Declaração dos Direitos do Homem de 1789” (JULIEN, 2014). Para o pensador, a saída é

10 A complexidade foi melhor desenvolvida por Edgar Morin e demanda outros trabalhos para melhor abordagem. A título de acréscimo, Morin destaca os lados bom e ruim da globalização, referindo-se à "mundialização civilizacional" que "se desenvolve, para o pior e para o melhor: para o pior, acarreta destruições culturais irremediáveis; homogeneíza e padroniza os costumes, os hábitos, o consumo, a alimentação (fast food), a viagem, o turismo; mas essa mundialização opera também para o melhor porque produz hábitos, costumes, gêneros de vida comuns através das fronteiras nacionais, étnicas, religiosas, rompendo um certo número de barreiras de incompreensões entre indivíduos ou povos." (MORIN; KERN, 2011, p. 37). 
amoldar o conceito para fazer dos Direitos Humanos transculturalmente aceitáveis a partir da abstração.

\title{
4 Da necessária mudança paradigmática para os Direitos Humanos: algumas críticas ao PL no 288/2013, do Senado Federal
}

Como já exposto, a Lei $n^{\circ}$ 6.815/1980 está focada na importância de se preservar os interesses e a segurança nacional. Mas, com as mudanças sugeridas no Projeto de Lei $\mathrm{n}^{\circ}$ 288/2013, do Senado Federal ${ }^{11}$, o destaque passa a ser o migrante, tirando, inclusive, a carga pejorativa que o termo "estrangeiro" traz, bem como o reflexo nos dispositivos a partir da globalização econômica, das guerras, dos regimes ditatoriais, dos desastres naturais e da pobreza, da assistência humanitária, da cooperação internacional e regional, e do desenvolvimento econômico, social e cultural do país. Em resumo, “(...) na democracia globalizada, o Homem configura a presença moral da cidadania" (BONAVIDES, 2008, p. 134), importando esclarecer que os Direitos Humanos não anulam a segurança nacional e vice-versa, eis que coexistem e, a falta de regulamentação eficaz pode trazer consequências drásticas, conforme se verifica nas colocações de Ermanno Vitale:

\begin{abstract}
Obviamente, si esta perspectiva llegara a ser plenamente reconocida ello no supondría que el derecho fundamental a migrar no tuviera que ser objeto de regulación, como cualquier otro derecho, mediante leyes ordinarias, traduciéndose finalmente en políticas migratorias. Supondría, por el contrario, que su ejercicio habría de ser regulado para permitir su disfrute, es decir, para producir políticas migratorias orientadas a proporcionar a quien lo desee la posibilidad de migración legal en un plazo de tiempo razonable, en lugar de cerrar cada vez más los canales de la migración legal, abandonando en gran medida la gestión del fenómeno, al fin y al cabo imparable, a los "poderes salvajes", a la clandestinidad, a la esclavización de los migrantes a manos de organizaciones criminales y empleadores sin escrúpulos. (VITALE, 2010, p. 539).
\end{abstract}

Em relatório, o Senador Ricardo Ferraço lembra que as políticas públicas decorrentes da inadequada legislação causaram violações aos Direitos Humanos e isso contribuiu para a imagem negativa que se criou da mobilidade humana. Cabe destacar o seguinte trecho:

(...) É dívida histórica do Brasil a consolidação de uma lei mais humanitária, coerente com a busca por uma sociedade justa, livre e democrática, que respeite os direitos humanos e seja ciente quanto à contribuição cultural, social e econômica dos imigrantes para o país. (SENADO FEDERAL, PL 288/2013).

\footnotetext{
${ }^{11}$ Seguindo a mesma linha de pensamento deste PL n ${ }^{\circ}$ 288/2013, do Senado Federal, embora com texto de outro teor e com outras previsões, há também o PL nº 5.655/2009, de autoria do Poder Executivo e em trâmite na Câmara dos Deputados.
} 
Nesta esteira, o artigo $3^{\circ}$ do PL 288/2013, do Senado Federal, estabelece entre os princípios da política migratória brasileira, a título de exemplo, o repúdio à xenofobia (inciso III), a acolhida humanitária (inciso VI), a garantia de reunião familiar (inciso VIII), a promoção de entrada regular e de regularização documental (inciso V) e a não discriminação em razão dos critérios e procedimentos pelos quais a pessoa foi admitida no território nacional (inciso IV).

Do mesmo modo, o artigo $4^{\circ}$ do PL 288/2013, do Senado Federal, elenca uma série de direitos e garantias fundamentais em prol dos imigrantes, colocando-os em patamar igualitário com os nacionais, inclusive para aqueles que adentraram o país sem o devido registro, resguardadas as proporções de direitos e deveres que dependem da documentação. Em relação a isso, cabe uma análise mais precisa, dentro da ênfase humanitária que o Senado pretende dar, vejamos.

De acordo com o artigo $4^{\circ}, \S 5^{\circ}$, do PL n ${ }^{\circ} 288 / 2013$, do Senado Federal, aplicam-se aos imigrantes não registrados, ou seja, àqueles que estão em situação irregular, os direitos previstos nos incisos I, II, IV, VI, VIII, X e XIII. São eles: direitos e liberdades civis, sociais, culturais e econômicos; direito à liberdade de circulação no território nacional; medidas de proteção às vítimas e testemunhas de crimes e violações de direitos; direito de reunião para fins pacíficos; acesso aos serviços públicos de saúde e de assistência social e previdência social, nos termos da lei; direito à educação pública, vedada a discriminação em razão da nacionalidade. Até aqui, pode-se observar que este Projeto de Lei assegura direitos e garantias, não cabendo fazer comentários restritivos, tendo em vista a intenção colocada pelo legislador.

O problema ocorre quando se verifica o rol de garantias que não foram mencionados no dispositivo acima citado. São as seguintes incisos, previstos no artigo $4^{\mathrm{o}}$ :

\footnotetext{
Art. $4^{\circ}(\ldots)$

III - direito à reunião familiar dos imigrantes com seus cônjuges e companheiros, filhos, familiares e dependentes;

$\mathrm{V}$ - direito de transferir recursos decorrentes de sua renda e economias pessoais a outro país, observada a legislação aplicável;

VII - direio de associação, inclusive sindical, para fins lícitos;

IX - amplo acesso à justiça e à assistência jurídica integral gratuita aos que comprovarem insuficiência de recursos;

XI - garantia de cumprimento de obrigações legais e contratuais trabalhistas e de aplicação das normas de proteção ao trabalhador;

XII - isenção das taxas de que trata esta Lei, mediante declaração de hipossuficiência econômica, na forma do regulamento;

XIV - direito a abertura de conta bancária;
} 
$\mathrm{XV}$ - direito a sair, permanecer e reingressar em território nacional, mesm enquanto pendente pedido de residência, prorrogação de estada ou transformação de visto em residência.

(PL n ${ }^{\circ}$ 288/2013, do Senado Federal, artigo $4^{\circ}$ ).

Verifica-se que, no caput do artigo $4^{\circ}$ do PL no 288/2013, o legislador fez a previsão de garantias para imigrantes. Entretanto, no $\S 5^{\circ}$, fala-se em "imigrantes não registrados", o que causa dúbia interpretação, pois ora se admite a aplicação de todas essas garantias a todos os imigrantes, ora se aplicam aos imigrantes não registrados apenas as que são colocadas no $\S$ $5^{\circ}$.

Ao que aparenta, a intenção do legislador foi diferenciar as garantias quanto aos imigrantes registrados e não-registrados, pois, se assim não o fosse, não teria se utilizado do adjetivo "registrado" qualificando o termo "imigrante"; e não teria sentido fazer um parágrafo específico referindo-se tão-somente aos imigrantes não registrados e, também, não seria necessário ter o registro, já que os direitos e garantias não sofreriam alterações e, por isso, seria indiferente ter ou não ter o registro.

Ocorre que, ao fazer estas distinções em termos de garantias voltadas a apenas uma dada categoria, leva o intérprete à reflexão e às propostas no sentido de verificar o que seria a melhor opção, levando-se em conta os princípios norteadores da hermenêutica a ser aplicada em consonância com a visão humanitária e com a era da globalização, o que pode causar incoerências.

Considerando que é fato notório a falta de controle fronteiriço no Brasil, até mesmo em razão da ampla extensão territorial o que, consequentemente, abre margem à entrada de imigrantes ilegais (sem registro), a falta de previsão legal de algumas garantias para essa categoria como, por exemplo, a garantia de cumprimento de obrigações legais e contratuais trabalhistas e de aplicação das normas de proteção ao trabalhador, associada à falta do direito de associação sindical, fragiliza as relações laborais, facilitando o trabalho escravo e o tráfico de pessoas, contrariando finalidade que se quer proteger com a aprovação desse projeto de lei. Aliás, o Brasil não é parte da Convenção da ONU sobre os Direitos dos Trabalhadores Migrantes e suas Famílias ${ }^{12}$.

\footnotetext{
${ }^{12}$ Em entrevista com o argentino Paulo Ceriani Cernades, membro do Comitê da ONU para Migrantes, a ONG Conectas - Direitos Humanos trouxe a informação de que, em relação à adesão dos países na Convenção da ONU sobre os Direitos dos Trabalhadores Migrantes e suas Famílias, "dos 47 Estados parte, 17 são da América Latina. Destes, 8 são sul-americanos. Só a Venezuela e o Brasil não aderiram na região." (CHARLEAUX, 2013).
} 
Para corroborar, a falta do direito à abertura de conta bancária pode trazer dificuldades ainda maiores no que tange às provas dos salários que um determinado imigrante não registrado recebe mensalmente, contribuindo mais para a desordem.

A questão jurídica de Direto do Trabalho envolvida neste cenário é de suma importância prática e vai de encontro com as normas internas e externas. Ressalta-se que a Constituição Federal de 1988, em vários dispositivos, trata dessas questões, de modo a não condizer com a interpretação dada à omissão de garantias a imigrantes não registrados. Destacamos os seguintes: o artigo $1^{\circ}$ e seus incisos, elenca a soberania, a cidadania, a dignidade da pessoa humana, os valores sociais do trabalho e da livre iniciativa e o pluralismo político como fundamentos da República Federativa do Brasil; o artigo $3^{\circ}$ traz, entre os objetivos fundamentais da República Federativa do Brasil, a construção de uma sociedade livre, justa e solidária, e a promoção do bem de todos; o artigo $4^{\circ}$ dispõe os princípios que regem as relações internacionais, entre eles a prevalência dos direitos humanos e a cooperação entre os povos para o progresso da humanidade. De forma mais específica, a Constituição Cidadã, nos artigos $6^{\circ}$ ao 11 , prevê os direitos sociais, com especial atenção para os direitos dos trabalhadores urbanos e rurais, além de assegurar o direito de greve.

Em âmbito internacional, a Declaração Universal dos Direitos Humanos, de 1948, assinada pelo Brasil, inspirada nos princípios da Revolução Francesa e em razão das atrocidades cometidas durante a $2^{\text {a }}$ Guerra Mundial, reproduz o conteúdo exposto na Constituição de 1988 , trazendo uma série de recomendações (COMPARATO, 2013, p. 237252).

Da mesma forma, o Pacto Internacional sobre Direitos Civis e Políticos (1966) e o Pacto Internacional sobre Direitos Econômicos, Sociais e Culturais (1966), ratificados pelo Brasil pelo Decreto Legislativo $n^{\circ}$ 226/1991 e promulgados pelo Decreto $n^{\circ}$ 592/1992, também trazem as mesmas recomendações protetivas (COMPARATO, 2013, p. 291-378).

Ainda em 1992, o Brasil promulgou a Convenção Americana sobre Direitos Humanos (1969) por meio do Decreto 678/1992, a qual "reproduza a maior parte das declarações de direitos constantes do Pacto Internacional de Direitos Civis e Políticos de 1966" (COMPARATO, 2013, p. 379).

Nota-se que o Brasil, tanto na esfera nacional, quanto na esfera internacional, tem normas de proteção a todas as pessoas, independentemente da condição de nacionalidade, isto é, não importa se é brasileiro ou imigrante, pela aplicação das normas acima referidas, todos têm o direito de acesso às condições que contribuam para alicerçar a dignidade da pessoa humana. 
Pelo que se percebe não há falta de normas que garantam o bem-estar de todos. Todavia, algumas restrições estabelecidas em determinados diplomas dão ensejo a uma infinidade de colocações diversas, acabando por prevalecer a desproteção, em detrimento de uma boa intenção camuflada em declarações de cunho não vinculante.

Em que pese o Brasil ser signatário da legislação internacional acima colacionada e da previsão constitucional em normas de aplicabilidade ampla e programática, a existência de outras leis e de projetos de lei, como é o caso, que se abrem a interpretações em sentido contrário, pode causar a desproteção de muitos. No exemplo já citado, observa-se que a falta de garantia de cumprimento de obrigações legais e contratuais trabalhistas em relação aos imigrantes não registrados desprotege a relação de trabalho, tanto para o empregado, quanto para o empregador.

Assim, a continuidade dessa previsão neste dispositivo do PL n ${ }^{\circ}$ 288/2013, do Senado Federal, além de causar tamanha desproteção, é obsoleta, diante da supremacia da Constituição Federal, bem como das normas e tratados internacionais sobre Direitos Humanos que, se aprovados em cada Casa do Congresso Nacional, em dois turnos, por três quintos dos votos dos respectivos membros, serão equivalentes às emendas constitucionais (artigo $5^{\circ}, \S 3^{\circ}$, da Constituição Federal).

Além disso, as omissões de garantias aos imigrantes não registrados está em dissonância com a suposta justificativa de adequar a legislação que trata da migração no Brasil com a globalização, lembrada em vários trechos dos relatórios redigidos pelos senadores, nas ocasiões em que o PL 288/2013 foi colocado em pauta nas discussões do Senado Federal.

Por outro lado, em relação às normas internacionais referidas, apesar do cunho protecionista, há que se deter ao contexto do período iluminista, em que prevaleciam os direitos individuais em detrimento dos direitos sociais. Talvez seja este o entendimento que traz os resquícios para os dias de hoje, ainda que de forma implícita, apesar de toda a evolução histórica dos direitos e garantias fundamentais em gerações ou dimensões ${ }^{13}$. Neste sentido, esclarece Ana Maria D’Ávila Lopes:

\footnotetext{
${ }^{13}$ Apesar de existir quem utilize os termos "gerações" e "dimensões" como sinônimos, há controvérsias quanto à nomenclatura para se caracterizar a evolução histórica dos direitos fundamentais. Paulo Bonavides (2006) utiliza a expressão "gerações dos direitos fundamentais". Entretanto, há quem entenda pela impropriedade destes termos, afirmando que o ideal seria falar em "dimensões dos direitos fundamentais", porque a palavra "geração" traz a equivocada ideia de sucessão, de modo que uma geração de direitos é substituída pela outra, quando, na verdade, são coexistentes, indivisíveis e complementares (neste sentido: SARLET, 2007; TRINDADE, 1997, v.1). Segundo Marmelstein (2008), a origem da divisão dos direitos fundamentais remonta à Aula Inaugural do Curso do Instituto Internacional dos Direitos do Homem, em Estraburgo, proferida pelo jurista tcheco Karel Vasak, que associou a evolução dos direitos fundamentais ao lema da Revolução Francesa. Assim, a $1^{\text {a }}$ dimensão
} 
La concepción liberal e individualista de los derechos humanos, que desde el Iluminismo había imperado, comenzó con la DUDH a ser objetada. No debe olvidarse de que el universo teórico iluminista, en el cual los derechos humanos se gestaron, estuvo impregnado de la concepción del ser humano em cuanto homo economicus. En ese contexto teórico, las relaciones intersubjetivas eran concebidas como uma lucha egoísta entre indivíduos pre-sociales y no como sujeitos pertenecientes a una comunidad y, como tales, responsables por ella. (LOPES, 2010, p. 13$).^{14}$

Embora a autora tenha fundamentos para fazer tais afirmações, o que, sem dúvidas, influencia a atualidade ao lidar com a problemática, por exemplo, da imigração, sobretudo em um meio que, apesar de chamado "global", ainda guarda fortes traços do individualismo ${ }^{15}$ como efeito colateral da própria conjuntura, o fato de negar direitos essenciais a imigrantes, mesmo que não registrados, não se justifica.

Este individualismo vem de mãos dadas com as questões de segurança que alicerçaram a ordem internacional anterior e foi retomado, principalmente, em 2001, com o ataque terrorista ocorrido nos Estados Unidos. Em que pese a ideia de "proteção de fronteiras", com o propósito de evitar atentados contra a ordem nacional, o que, em contrapartida, contribui para marginalizar imigrantes que não deveriam arcar com responsabilidade por algo que não cometeram, os imigrantes ilegais, entendidos pelo sociólogo polonês Zygmunt Bauman (2005) como o refugo da globalização, são, muitas vezes, utilizados em motivações políticas de campanhas eleitorais, um "outro desviante":

(...) Há uma espécie de 'afinidade eletiva' entre os imigrantes (aquele refugo humano proveniente de lugares distantes descarregado em 'nosso próprio quintal') e os menos toleráveis de nossos próprios temores domésticos. Quando todos os

corresponde aos direitos civis e político (liberdade). A $2^{\text {a }}$ dimensão abrange os direitos sociais, econômicos e culturais (igualdade). E a $3^{\mathrm{a}}$ dimensão remete à solidariedade (fraternidade). Atualmente, há, também, discussões sobre a existência de outras gerações ou dimensões de direitos fundamentais, apesar de não haver consenso. Norberto Bobbio (2004) fala em direitos de $4^{\mathrm{a}}$ dimensão, os quais se relacionam à Engenharia Genética. Bonavides (2006), igualmente, entende que há $4^{\mathrm{a}}$ dimensão, porém incluem-se os direitos à democracia, à

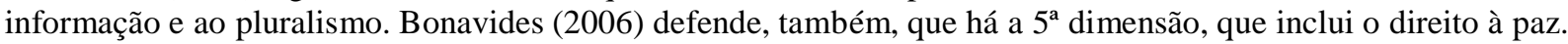
Majid Tehrarian (apud SAMPAIO, 2004, p. 302) diz que a $5^{a}$ dimensão dos direitos fundamentais refere-se ao cuidado, à compaixão e ao amor por todas as formas de vida, enquanto Abu Marzouki (apud SAMPAIO, 2004, p. 302) argumenta que refere-se à biofísica, que causa preconceito quanto à raça reputada como inferior. Zulmar Fachin e Deise Marcelino da Silva (2010) colocam o direito ao acesso à água potável como de $6^{\mathrm{a}}$ dimensão. (MARINO; RAMPAZZO, no prelo).

${ }^{14}$ Tradução livre: A concepção liberal e individualista dos Direitos Humanos, que desde o Iluminismo havia imperado, começou com a Declaração Universal dos Direitos Humanos, a ser objetada. Não se deve duvidar de que o universo teórico iluminista, no qual os Direitos Humanos nasceram, estava impregnado da concepção de ser humano enquanto homo economicus. Neste contexto teórico, as relações intersubjetivas eram concebidas como uma luta egoísta entre indivíduos pré-sociais, e não como sujeitos pertencentes a uma comunidade e, como tais, responsáveis por ela.

15 Lopes (2010, p. 16) explica que a necessidade de reconstrução da sociedade no pós-guerra reforçou os interesses egocêntricos. 


\begin{abstract}
lugares e posições parecem balançar e não são mais considerados confiáveis, a presença de imigrantes joga sal na ferida. Os imigrantes, e em particular os recémchegados, exalam o odor opressivo do depósito de lixo que, em seus muitos disfarces, assombra as noites das potenciais vítimas da vulnerabilidade crescente. Para aqueles que os destratam e odeiam, os imigrantes encarnam - de modo visível, tangível em carne e osso - o pressentimento inarticulado, mas pugente e doloroso, de sua própria condição de descartável. Fica-se tentado a dizer que, se não houvesse imigrantes batendo às portas, eles teriam de ser inventados... De fato, eles fornecem aos governos um 'outro desviante' ideal, um alvo muito bem-vindo para 'temas de campanha selecionados com esmero’. (BAUMAN, 2005, p. 73).
\end{abstract}

É certo que, pelos dados estatísticos que se tem notícia, aproximadamente $1 \%$ da população brasileira é formada por imigrantes, número pequeno, se comparado à média no mundo (3\%) (PARISE, 2015). Contudo, a adequação da legislação brasileira à ordem internacional é de fundamental importância, diante do dinamismo dos fatos que requer respostas jurídicas, posição esta defendida por Andres Ramírez, representante do Alto Comissariado das Nações Unidas para Refugiados (ACNUR), e por Felipe González, relator sobre direito dos migrantes da Organização dos Estados Americanos (OEA) e membro da Comissão Interamericana de Direitos Humanos.

Mais importante ainda é a visão crítica de todo este contexto de crise humanitária, porque por detrás dessa estatística, há todo o processo histórico de formação do Brasil, já descrito em um dos itens anteriores, sem contar os imigrantes sem registro e que não são contabilizados, acabando por se chegar num dado numérico não confiável, o que contribui para aumentar as dificuldades de implementação de políticas públicas urgentes.

Considerando todo este quadro, é importante garantir a dignidade também àqueles que não têm registro, sob pena de cair no vazio de uma universalização vazia dos Direitos Humanos, tornando letra morta tudo o que está escrito na lei, em razão do excesso de abstração sem quaisquer concreções, fatos muito bem descritos pela pensadora Hanna Arendt, em sua obra "Origens do Totalitarismo" (2013).

Dessa forma, convém repensar a redação do artigo $4^{\circ}$ do PL $n^{\circ} 288 / 2013$, a fim de estender a garantia do cumprimento de obrigações legais e contratuais trabalhistas, a aplicação das normas de proteção ao trabalhador, o direito de associação sindical e o direito de abertura de conta bancária também aos imigrantes não registrados.

\title{
Considerações Finais
}

Retomando a problemática inicial no que se refere às defasagem legislativa nas normas migratórias do Brasil, torna-se evidente a necessidade de modificações no intuito de 
adequar-se ao mundo globalizado, que requer a mitigação das tradicionais ideias de soberania entre os Estados e de cidadania, prevalecendo os Direitos Humanos, mas, ao mesmo tempo, zelando pela segurança do país.

Busca-se, portanto, aprimorar as normas legais, trazendo eficácia jurídica ao que é vivido socialmente, em razão de dívida histórica, pois a atual legislação baseia-se no contexto da Ditadura Militar, em que prevalecia a segurança nacional. Hoje, transforma-se este viés e o respaldo que se tem são os Direitos Humanos, com as limitações da crise do Estado Social decorrente da universalização do que se almeja ter, mas que guarda distância quando o foco é empírico.

Assim, com o fim de tornar eficaz essa interpretação de cunho humanitário, o próprio PLn $n^{\circ}$ 288/2013 necessita adequar-se, com destaque para o artigo $4^{\circ}, \S 5^{\circ}$, que restringiu algumas garantias elementares aos imigrantes não registrados. Propõe-se, a partir daí, a extensão das garantias do cumprimento de obrigações legais e contratuais trabalhistas, de aplicação das normas de proteção ao trabalhador e do direito de associação sindical, também aos imigrantes não registrados porque, apesar da situação de ilegalidade ao entrar e permanecer no Brasil, caso se negue essas garantias, os efeitos podem ser mais drásticos como, por exemplo, estimularia a escravidão e o tráfico de pessoas.

\section{Referências}

ARENDT, Hanna. Origens do Totalitarismo. Tradução de Roberto Raposo. São Paulo: Campanhia de Bolso, 2013.

ATIENZA, Manuel. Para una razonable definición de 'razonable'. In: Doxa: Cuadernos de Filosofía del Derecho, n. 4, 1987, p. 189-200. Alicante: Biblioteca Virtual Miguel de Cervantes, 2001. Disponível em: <http://www.cervantesvirtual.com/obra/para-una-razonable- definicionde-razonable/>. Acesso em: 20 jun. 2015.

BAUMAN, Zygmunt. Vidas Desperdiçadas. Tradução de Carlos Alberto Medeiros. Rio de Janeiro: Jorge Zahar, 2005.

BOBBIO, N. A Era dos Direitos. Tradução de Carlos Nelson Coutinho. Apresentação de Celso Lafer. 2 ed. Rio de Janeiro: Elsevier, 2004.

BONAVIDES, Paulo. Os Direitos Fundamentais e a Globalização. In: LEITE, George Salomão (Coord.). Dos Princípios Constitucionais: considerações em torno das normas principiológicas da Constituição. 2. ed. São Paulo: Método, 2008. p. 129-140.

Curso de Direito Constitucional. 19. ed. São Paulo: Malheiros, 2006. 
BRASIL. Anteprojeto de Lei de Migrações e Promoção dos Direitos dos Migrantes no Brasil. Brasília: Ministério da Justiça, Comissão de Especialistas, 2014. Disponível em: <http://library.fes.de/pdf-files/bueros/brasilien/10947.pdf>. Acesso em: 20 jun. 2015.

Câmara dos Deputados. Projeto de Lei $n^{\circ}$ 5.655/2009. Disponível em:

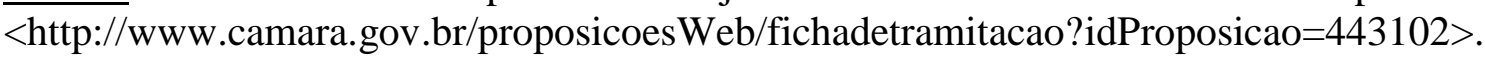
Acesso em: 20 jun. 2015.

$$
\text { Constituição Federal de 1988. Disponível em: }
$$

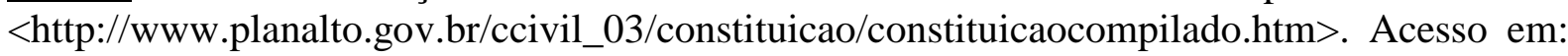
25 jun. 2015.

- Decreto $\mathrm{n}^{\mathrm{o}}$ 86.715, de 10 de dezembro de 1981. Disponível em: <http://www.planalto.gov.br/ccivil_03/decreto/Antigos/D86715.htm>. Acesso em: 20 jun. 2015.

. Decreto $\mathrm{n}^{\mathrm{o}}$ 70.391, de 12 de abril de 1972. Disponível em:

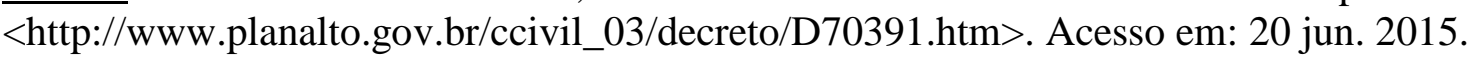

. Decreto $\mathrm{n}^{\mathrm{o}}$ 19.841, de 22 de outubro de 1945. Disponível em: <http://www.planalto.gov.br/ccivil_03/decreto/1930-1949/d19841.htm>. Acesso em: 20 jun. 2015.

Lei $\mathrm{n}^{\mathrm{o}}$ 6.815, de 19 de agosto de 1980. Disponível em:

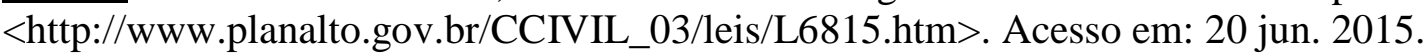

Senado Federal. Projeto de Lei $n^{\circ}$ 288/2013. Disponível em: $\langle$ http://www.senado.gov.br/atividade/materia/detalhes.asp?p_cod_mate $=113700\rangle$. Acesso em: 20 jun. 2015.

CANOTILHO, Joaquim José Gomes. Direito Constitucional. 5. ed. Coimbra: Almedina, 1992.

CHARLEAUX, João Paulo. Adital: Entrevista - Brasil deve aderir sem demora a tratado que protege migração. Conectas, 18 dez. 2013. Disponível em: <http://www.conectas.org/pt/acoes/midia/noticia/12543-adital-entrevista-brasil-deve-aderirsem-demora-a-tratado-que-protege-migracao>. Acesso em: 20 jun. 2015.

CLARO, Carolina de Abreu Batista. As Migrações Internacionais no Brasil sob uma perspectiva jurídica: análise da legislação brasileiras sobre estrangeiros entre os séculos XIX e XXI. Cadernos OBMigra - Revista Migrações Internacionais, v. 1, n. 1, 2015, Brasília: UnB. Disponível em: <http://periodicos.unb.br/index.php/obmigra/article/view/13116>. Acesso em: 10 jun. 2015.

COMPARATO, Fábio Konder. A Afirmação Histórica dos Direitos Humanos. 8. ed. São Paulo: Saraiva, 2013. 
D'AURIA, Matthew. Insegnamento di Diritto Internazionale. Lezione I: Nozione Introduttive. Pegaso: Università Telematica, 2013. Disponível em: <http://www.mlnsardu.org/wordpress/wp-content/uploads/2013/09/linsegnamento-di-dirittointernazionale.pdf>. Acesso em: 25 jun. 2015.

DIDEROT, D.; D'ALEMBERT, J. L. R. (1751/1765). Artículos políticos de la Enciclopedia. Ed. cast. de R. Soriano y A. Porras. Madrid: Tecnos, 1986.

EL PAÍS. É urgentíssimo aprovar a nova lei de imigração. Entrevista com Paulo Sérgio de Almeida. Disponível em: <http://brasil.elpais.com/brasil/2015/05/28/politica/1432823272_043541.html>. Acesso em: 20 jun. 2015.

ESTILO Europeu. Casa São Mateus. Disponível em: <http://www.casasaomatheus.com.br/casa/estilo-europeu-a69.htm>. Acesso em: 25 jun. 2015.

FACHIN, Zulmar; SILVA, Deise Marcelino da. Acesso à água potável: Direito Fundamental de Sexta Dimensão. Campinas: Millenium, 2010.

FAUSTO, Boris. História do Brasil. 2. ed. São Paulo: Universidade de São Paulo; Fundação do Desenvolvimento da Educação, 1995. (Didática, I).

FERRAJOLI, Luigi. Las Garantías Constitucionales de los Derechos Fundamentales. In: Doxa: Cuadernos de Filosofía del Derecho, n. 29, 2006, p. 15-31. Alicante: Biblioteca Virtual Miguel de Cervantes, 2009. Disponível em: <http://www.cervantesvirtual.com/obra/lasgarantas-constitucionales-de-los-derechos-fundamentales-0/>. Acesso em: 25 jun. 2015.

FLORES, Joaquín Herrera. Direitos Humanos, interculturalidade e racionalidade de resistência. Tradução de Carol Proner. Revista Sequência, v. 23, n. 44, Florianópolis, UFSC, 2002. Disponível em: <https://periodicos.ufsc.br/index.php/sequencia/article/view/15330>. Acesso em: 25 jun. 2015.

HELLER, Hermann. Teoria do Estado. Tradução de Lycurgo Gomes da Motta. São Paulo: Mestre JOU, 1968.

IBGE. Censo Demográfico de 2010. Disponível em: <http://www.ibge.gov.br/home/estatistica/populacao/censo2010/default.shtm>. Acesso em: 25 jun. 2015.

JULIEN, François. Os direitos do homem são mesmo universais? Le Monde Diplomatique Brasil, 14 jan. 2014. Disponível em: <www.diplomatique.org.br/artigo.php?id=145>. Acesso em: 25 jun. 2015.

KANT, Immanuel. Para a Paz Perpétua. Tradução de Bárbara Kristensen e Estudo Introdutório de Joám Evans Pim. Rianxo: Instituto Galego de Estudos de Segurança Internacional e da Paz, 2006. (Ensaios sobre Paz e Conflitos, v. V).

KYMLICKA, Will. Multicultural Citizenship. Oxford University, 1995. 
LOPES, Ana Maria D’Ávila. La Declaración Universal de los Derechos Humanos: el inicio de la reconstrucción de la teoria de la ciudadanía. In: FOLMANN, Melissa; ANNONI, Danielle (Coords). Direitos Humanos: os 60 anos da Declaração Universal da ONU. Curitiba: Juruá, 2010. p. 11-18.

MARINO, Aline Marques; RAMPAZZO, Lino. Refugiados Ambientais: breves comentários sobre o caso dos imigrantes haitianos no Brasil após o terremoto de 2010, no Haiti. Revista Direitos Humanos Fundamentais, Osasco: Programa de Mestrado em Direito da Unifieo. (No prelo).

MARMELSTEIN, George. Curso de Direitos Fundamentais. São Paulo: Atlas, 2008.

MILESI, Rosita. Por uma nova Lei de Migração: a perspectiva dos Direitos Humanos. Instituto Migrações e Direitos Humanos. Disponível em: <http://www.mp.go.gov.br/portalweb/hp/41/docs/por_uma_nova_lei_migracao.pdf $>$. Acesso em: 20 jun. 2015.

MORIN, Edgar; KERN, Anne-Brigitte. Terra-Pátria. Tradução de Paulo Neves da Silva. 6. ed. Porto Alegre: Sulina, 2011.

NEVES, Marcelo. Transconstitucionalismo. São Paulo: Martins Fontes, 2009.

ORDAZ, Pablo. Itália resgata 4.500 imigrantes no Mar Mediterrâneo no fim de semana. El País, 03 maio 2015.2 Disponível em: <http://brasil.elpais.com/brasil/2015/05/02/internacional/1430598140_601252.html>. Acesso em: 20 jun. 2015.

OS CONSTITUCIONALISTAS. Marcelo Neves e o Transconstitucionalismo, 02 dez. 2009. Disponível em: <http://www.osconstitucionalistas.com.br/marcelo-neves-e-otransconstitucionalismo >. Acesso em: 20 jun. 2015.

PARISE, Paolo. Imigração no Brasil: os números e os desafios sociais e éticos. In: $\mathbf{1}^{\mathbf{o}}$ Simpósio Internacional sobre Religião e Migração: mobilidade humana e identidades religiosas. São Paulo: CEM, PUCSP, SIMI, 8 a 10 de junho de 2015. Disponível em: <https://drive.google.com/folderview?id=0B8G22TOAEkrHfmdhSDZ6ak95SGJUcmhOZTV obUpsRHRjdXNKTEk5U11XcGRCLW1mT3dneW8\&usp=sharing>. Acesso em: 25 jun. 2015.

PEREZ LUÑO, Antonio-Enrique. Ciudadanía y Definiciones. Doxa: Cuadernos de Filosofía del Derecho, n. 25, 2002, p. 177-211. Alicante: Biblioteca Virtual Miguel de Cervantes, 2005. Disponível em: <http://www.cervantesvirtual.com/obra/ciudadana-y-definiciones-0/>. Acesso em: 25 jun. 2015.

PIOVESAN, Flávia. Direitos Humanos e o Direito Constitucional Internacional. Rio de Janeiro: Max Limonad, 1996.

PISÓN, José Martínez. Tolerancia y Derechos Fundamentales en las sociedades multiculturales. Madrid: Tecnos, 2001.

RAMALHO, Renan. Governo vai aumentar vistos para haitianos virem ao Brasil, diz 
Ministro. G1, 04 jun. $2015 . \quad$ Disponível em: <http://g1.globo.com/politica/noticia/2015/06/governo-vai-aumentar-vistos-para-haitianosvirem-ao-brasil-diz-ministro.html>. Acesso em: 25 jun. 2015.

ROTA do Enxaimel. Prefeitura de Pomerode: a cidade mais alemã do Brasil. Disponível em: <http://www.pomerode.sc.gov.br/AtrativosTuristicos7.asp>. Acesso em: 25 jun. 2015.

SAMPAIO, J. A. L. Direitos Fundamentais: retórica e historicidade. Belo Horizonte: Del Rey, 2004.

SANTINI, Daniel. Imigrantes. São Paulo: Repórter Brasil; Catholic Relief Services, 15 dez. 2014. Disponível em: <http://imigrantes.webflow.io/>. Acesso em: 25 jun. 2015.

SANTOS, Boaventura de Sousa (Org.). Democratizar a democracia: os caminhos da democracia participativa. Rio de Janeiro: Civilizaçãp Brasileira, 2002.

SARLET, Ingo Wolfgang. A Eficácia dos Direitos Fundamentais. 8. ed. Porto Alegre: Livraria do Advogado, 2007.

- Os Direitos Fundamentais Sociais na Constituição de 1988. Revista Diálogo Jurídico, Salvador, ano I, v. I, abr. 2001. Disponível em: <http://www.direitopublico.com.br/pdf_seguro/REVISTA-DIALOGO-JURIDICO-01-2001INGO-SARLET.pdf $>$. Acesso em: 20 jun 2015.

SENADO Federal. Brasil precisa rever Lei de Imigração, diz procurador de direitos do cidadão, 05 jun. 2014.2 Disponível em: <http://www12.senado.gov.br/noticias/materias/2014/06/05/brasil-precisa-rever-lei-deimigracao-diz-procurador-de-diretos-do-cidadao/tablet>. Acesso em: 20 jun. 2015.

SILVA, José Afonso da. Aplicabilidade das Normas Constitucionais. 2. ed. São Paulo: Revista dos Tribunais, 1982.

SIQUEIRA JÚNIOR, Paulo Hamilton; OLIVEIRA, Miguel Augusto Machado de. Direitos Humanos e Cidadania. 3. ed. São Paulo: RT, 2010.

TORRES, Ricardo Lobo. A Cidadania Multidimensional na Era dos Direitos. In:

(Org.). Teoria dos Direitos Fundamentais. 2. ed. Rio de Janeiro: Renovar, 2001. p. $\overline{243-342 .}$

TRINDADE, Antonio Augusto Cançado. Tratado de Direito Internacional dos Direitos Humanos. Porto Alegre: Sérgio Antonio Fabris, 1997. v. I.

VENTURA, Deisy; REIS, Rossana Rocha. Criação de lei de igrações é dívida histórica do Brasil. Carta Capital, 21 ago. 2014. Disponível em: $<$ http://www.cartacapital.com.br/sociedade/divida-historica-uma-lei-de-migracoes-para-obrasil-9419.html>. Acesso em: 20 jun. 2015.

VITALE, Ermanno. Modelos normativos de sociedad y migraciones.ARBOR Ciencia, Pensamiento y Cultura, CLXXXVI, 744, jul./ago. 2010, p. 531-541. Disponível em: $<$ http://arbor.revistas.csic.es/index.php/arbor/article/view/1207/1212>. Acesso em: 20 jul. 2015. 